\title{
Effects of salinity on growth and survival in five Artemia franciscana (Anostraca: Artemiidae) populations from Mexico Pacific Coast
}

\author{
Jorge Castro-Mejía ${ }^{1}$, Talía Castro-Barrera ${ }^{1}$, Luis Héctor Hernández-Hernández² ${ }^{2}$ José Luis
}

Arredondo-Figueroa ${ }^{3}$, Germán Castro-Mejía ${ }^{1}$ \& Ramón de Lara-Andrade ${ }^{1}$

1. Laboratorio Alimento Vivo, Departamento El Hombre y su Ambiente, Universidad Autónoma MetropolitanaXochimilco, Calzada del Hueso No.1100, Colonia Villa Quietud, Distrito Federal, 04960, México, Tel 5255-5483 7151; camj7509@correo.xoc.uam.mx, cabt7515@correo.xoc.uam.mx, gecastromejia@correeo.xoc.uam.mx, rlara@correo.xoc.uam.mx

2. Laboratorio de Producción Acuícola (Acuario), UNAM FES Iztacala, Av. de los Barrios 1, Los Reyes Iztacala Tlalnepantla, Estado de México, 54090, México, Tel 5255-56231197; luish3@yahoo.com

3. Planta Experimental de Producción Acuícola, Universidad Autónoma Metropolitana-Iztapalapa, Avenida San Rafael Atlixco No. 186, Colonia Vicentina, Distrito Federal, 09340, México, Tel 5255-58046585; afj1@xanum.uam.mx

$$
\text { Received 23-XI-2009. Corrected 02-VIII-2010. Accepted 01-IX-2010. }
$$

\begin{abstract}
Salinity is an important factor influencing growth and survival of aquatic organisms such as Artemia, a valuable aquaculture species. This study evaluated the effects of salinity on A. franciscana populations from different water bodies in Mexico's Pacific Coast. With this purpose, five autochthonous bisexual Artemia populations were tested to assess their survival and growth values against salinities of 40,60, 80, 100 and $120 \mathrm{~g} / \mathrm{l}$, under laboratory conditions $\left(25 \pm 2^{\circ} \mathrm{C}\right.$; $\mathrm{pH} 8-10$; constant light and aeration). The organisms were fed with $100 \mathrm{~mL}$ of rice bran and $2 \mathrm{~L}$ of Tetraselmis suecica $(500000 \mathrm{cel} / \mathrm{ml})$. The culture experiments were made in 200L plastic tanks, and survival and growth final values were obtained after 21 culture days. Survival and growth curves were determined by a regression analysis $\left(\mathrm{R}^{2}\right)$. The significant differences between salinities were determined by ANOVA test $(\mathrm{p}<0.05)$. The best survival and growth rates were found at salinities of $100-120 \mathrm{~g} / \mathrm{l}$. When the Mexican Artemia populations were cultivated at $40 \mathrm{~g} / 1$ of salinity, $100 \%$ mortality was observed in the juvenile stage. This study determined that survival and growth values of $A$. franciscana populations increased with salinity. The five A. franciscana populations presented significant differences in their survival rate under various salinity regimes. The studied populations experienced high mortality at salinities under $60 \mathrm{~g} / \mathrm{l}$ and over $200 \mathrm{~g} / \mathrm{l}$, and especially during the metanauplius stage. The present study confirms that growth rates in Mexican A. franciscana populations from Pacific Coast habitats are not inversely proportional to salinity. These A. franciscana populations should be cultured at $100-120 \mathrm{~g} / 1$ of salinity to obtain better survival and growth rates. This data is useful to improve culture systems in aquaculture biomass production systems. Rev. Biol. Trop. 59 (1): 199-206. Epub 2011 March 01.
\end{abstract}

Key words: Artemia franciscana, salinity, growth, survival, Mexico, Pacific Coast.

The genus Artemia (Crustacea: Anostraca) consists of bisexual and parthenogenetic species that are morphologically and biometrically similar. A group named "New World" species is composed of A. franciscana (Kellogg 1906) (North, Central and South America), A. persimilis (Piccinelli \& Prosdocimi 1968) (Argentina) and A. monica (Verril 1869) (USA); another group named "Old World" species is represented by A. salina (Leach 1819) (Mediterranean basis), A. urmiana (Günther 1900) (Urmia lake, Iran), A. sinica (Cai 1989) (China and neighboring countries), A. tibetiana (Abatzopoulos et al. 1998) (Tibet’s high Plateau), Artemia sp. (Pilla \& Beardmore 1994) (Kazakhstan) and parthenogenetic forms located only in the Old 
World, i.e., A. parthenogenetica (Abatzopoulos et al. 2002). The genus Artemia comprises a complex of sibling species and superspecies defined by a criterion of reproductive isolation (Browne \& Bowen 1991).

These organisms are largely distributed in inland and coastal hypersaline body waters (Triantaphyllidis et al. 1998, Castro et al. 2000, Van Stappen 2002, El-Bermawi et al. 2004). Artemia may inhabit chloride, sulphate or carbonate waters and combinations of more than two anions (Bowen et al. 1985, Lenz 1987). Artemia are among the few organisms that can adapt to very diverse living conditions, including salinities as low as $10 \mathrm{~g} / \mathrm{L}$ (Abatzopoulos et al. 2006a, Abatzopoulos et al. 2006b) and high as $340 \mathrm{~g} / \mathrm{L}$ (Post \& Youssef 1977).

Some information is available on the survival and growth rate characteristics of bisexual and parthenogenetic Artemia populations (Vanhaecke et al. 1984, Browne et al. 1984, Wear \& Haslett 1986, Browne \& Bowen 1991, Triantaphyllidis et al. 1995, Triantaphyllidis et al. 1997a, Triantaphyllidis et al. 1997b, Browne \& Wanigasekera 2000, Abatzopoulos et al. 2003, Baxevanis et al. 2004, Castro 2004, El-Bermawi et al. 2004, Abatzopoulos et al. 2006b, Agh et al. 2008) cultivated in different salinities. Most of these studies mentioned morphometry, life span and reproductive characteristics and also contributed to the evaluation of genetic and environmental components of variance in sexual and clonal Artemia. However, the importance of salinity as a principal factor modifying growth and survival of world Artemia populations and the effects of the salinity on A. franciscana populations from Mexico's Pacific Coast have been little studied, if at all.

The aim of this study was to determine the effects of salinity on the survival and growth values of five Pacific Coast Mexican Artemia populations cultured in laboratory at five salinities, to provide additional data for a better understanding of their adaptation patterns. This data can be useful for a better culture system in aquaculture biomass production.

\section{MATERIAL AND METHODS}

\section{Populations used in the experiment:} This study was conducted at the Laboratorio de Alimento Vivo of the Universidad Autónoma Metropolitana-Xochimilco, Mexico. The locations from where the cysts were collected are listed in Table 1.

TABLE 1

List of Mexican A. franciscana populations studied in this work, abbreviations used and geographical locations

\begin{tabular}{lccc}
\multicolumn{1}{c}{ Site } & State & Abbreviation & Geographical location \\
Yavaros & Sonora & YAV & $26^{\circ} 41^{\prime} \mathrm{N} ; 109^{\circ} 31^{\prime} \mathrm{W}$ \\
Bahía de Lobos & Sonora & LOBOS & $27^{\circ} 18^{\prime} \mathrm{N} ; 110^{\circ} 30^{\prime} \mathrm{W}$ \\
Ohuira & Sinaloa & OHUI & $24^{\circ} 18^{\prime} \mathrm{N} ; 107^{\circ} 22^{\prime} \mathrm{W}$ \\
El Marquéz & Oaxaca & MARQ & $16^{\circ} 09^{\prime} \mathrm{N} ; 95^{\circ} 14^{\prime} \mathrm{W}$ \\
Juchitán & Oaxaca & JUCH & $16^{\circ} 26^{\prime} \mathrm{N} ; 95^{\circ} 01^{\prime} \mathrm{W}$
\end{tabular}

Culture experiments: The cysts used in this study were stored at $-10^{\circ} \mathrm{C}$ to keep dehydration. An amount of $0.5 \mathrm{~g}$ of cyst from each strain were hatched at $40 \mathrm{~g} / \mathrm{l}$ of salinity, a $\mathrm{pH}$ of $8-10$, and a water temperature of $24 \pm 2^{\circ} \mathrm{C}$, and under conditions of constant illumination and aeration (Castro et al. 2003, Castro 2004). The newly hatched nauplii were placed into separate tanks and then transferred to 2001 plastic tanks with 1601 of differing salinities $(40,60$, $80,100$ and $120 \mathrm{~g} / \mathrm{l})$. The density of the Artemia nauplii was adjusted to one organism per $100 \mathrm{ml}$ to avoid crowding and growth problems. The animals were fed $100 \mathrm{ml}$ of rice bran $(75 \mathrm{~g} / 1$ 
per $90 \mathrm{~g} / 1$ saline water) and 21 of Tetraselmis suecica (500 000 cells $/ \mathrm{ml})$. The organisms were cultured until adulthood, when it was possible to observe mating. Culture conditions maintained in plastic tanks were: temperature of $24 \pm 2^{\circ} \mathrm{C}, \mathrm{pH}$ of $8-10$ and dissolved oxygen of $2 \mathrm{mgO}_{2} / \mathrm{ml}$.

Survival rate: The survival value was determined after 21 culture days; the mean density was taken by counting ten $500 \mathrm{ml}$ samples. The results (expressed as percentages) were log-transformed and plotted against time (expressed in days).

Growth rate: One hundred sexually mature organisms (50 females and 50 males) were separated from each population to obtain total length (TL) biometry data. Adult organisms were preserved with drops of acetic acid and the TL was measured with a dissection microscope equipped with a camera and Image-ProPlus 7.0 (MediaCybernetics ${ }^{\circledR}$ ) software program.

For data analysis, stem and leaf displays and Box Plot were performed to ensure that the assumption of normality was met for each data set. A descriptive statistical analysis was made to obtain mean values and standard deviation for length biometry. Analyses of variance (ANOVA) were also used to determine significant differences among the five populations (Tatsuoka 1970, Kachigan 1991). The least significant differences (LSD) pairwise comparison (Tukey; $\mathrm{p}<0.05$ ) was used to compare pairs of sample means after ANOVAs for TL character studied were generated. Type classifications were based on populations, and were grouped for biometric analysis according to the specific salinity of their culture medium (Sokal \& Rohlf 1981, Kachigan 1991). The SYSTAT 10.2 (Systat Software Inc., California, USA) software package was used for the statistical analysis.

Regression analysis (Sokal \& Rohlf 1981) for the survival and growth rates of each population and salinity was performed with the Excel 2003 statistical program (Microsoft Corp. Washington, USA).

\section{RESULTS}

Survival: The respective means and standard deviation values are shown in Table 2. Organisms from all populations at $40 \mathrm{~g} / \mathrm{l}$

TABLE 2

Mean values \pm standard deviation of survival $(\%)$ and total length $(\mathrm{mm})$ of the five Mexican A. franciscana Pacific Coast populations studied

\begin{tabular}{|c|c|c|c|c|c|c|c|c|}
\hline \multirow{3}{*}{ Populations } & \multicolumn{8}{|c|}{ Salinities $(\mathrm{g} / \mathrm{L})$ used in experiment } \\
\hline & \multicolumn{2}{|c|}{60} & \multicolumn{2}{|c|}{80} & \multicolumn{2}{|c|}{100} & \multicolumn{2}{|c|}{120} \\
\hline & Survival & TL & Survival & $\mathrm{TL}$ & Survival & $\mathrm{TL}$ & Survival & $\mathrm{TL}$ \\
\hline \multirow[t]{2}{*}{ YAV } & $37.62^{\mathrm{a}}$ & $7.178^{\mathrm{a}}$ & $65.22^{\mathrm{a}}$ & $6.542^{\mathrm{a}}$ & $79.31^{\mathrm{a}}$ & $7.907^{\mathrm{a}}$ & $78.76^{\mathrm{a}}$ & $8.019^{\mathrm{a}}$ \\
\hline & \pm 4.33 & \pm 0.431 & \pm 4.22 & \pm 0.290 & \pm 6.10 & \pm 0.150 & \pm 3.40 & \pm 0.246 \\
\hline \multirow[t]{2}{*}{ LOBOS } & $46.90^{\mathrm{b}}$ & $7.221^{\mathrm{a}}$ & $62.65^{\mathrm{b}}$ & $6.581^{\mathrm{a}}$ & $75.57^{b}$ & $7.954^{\mathrm{a}}$ & $80.54^{\mathrm{a}, \mathrm{b}}$ & $8.067^{\mathrm{a}}$ \\
\hline & \pm 4.31 & \pm 0.555 & \pm 5.56 & \pm 0.224 & \pm 3.35 & \pm 0.183 & \pm 6.12 & \pm 0.398 \\
\hline \multirow[t]{2}{*}{ OHUI } & $34.04^{\mathrm{c}}$ & $6.996^{\mathrm{b}}$ & $64.54^{\mathrm{a}}$ & $6.376^{\mathrm{b}}$ & $79.49^{\mathrm{a}}$ & $7.706^{\mathrm{b}}$ & $84.55^{\mathrm{b}, \mathrm{c}}$ & $7.815^{\mathrm{b}}$ \\
\hline & \pm 6.88 & \pm 0.468 & \pm 4.52 & \pm 0.188 & \pm 5.68 & \pm 0.133 & \pm 3.65 & \pm 0.271 \\
\hline \multirow[t]{2}{*}{ MARQ } & $47.86^{\mathrm{b}}$ & $7.720^{\mathrm{c}}$ & $64.76^{\mathrm{a}}$ & $7.035^{\mathrm{c}}$ & $77.81^{\mathrm{a}, \mathrm{b}}$ & $8.504^{c}$ & $78.99^{\mathrm{a}}$ & $8.624^{\mathrm{c}}$ \\
\hline & \pm 4.07 & \pm 0.540 & \pm 6.09 & \pm 0.178 & \pm 6.52 & \pm 0.168 & \pm 4.27 & \pm 0.366 \\
\hline \multirow[t]{2}{*}{$\mathrm{JUCH}$} & $35.70^{\mathrm{a}, \mathrm{c}}$ & $8.297^{\mathrm{d}}$ & $67.05^{\mathrm{c}}$ & $7.561^{\mathrm{d}}$ & $79.56^{\mathrm{a}}$ & $9.139^{\mathrm{d}}$ & $80.40^{\mathrm{a}}$ & $9.269^{\mathrm{d}}$ \\
\hline & \pm 5.86 & \pm 0.439 & \pm 4.84 & \pm 0.139 & \pm 3.94 & \pm 0.155 & \pm 3.88 & \pm 0.263 \\
\hline
\end{tabular}

Populations sharing similar letter(s) in each column are not significantly different (Tukey, $\mathrm{p}<0.05)$. TL=total length. 
salinity died after seven culture days (during the transition period of metanauplii to the juvenile stages). All populations showed their lowest survival rates after 21 days with a salinity of $60 \mathrm{~g} / \mathrm{l}$. Almost all populations showed the highest survival level at $120 \mathrm{~g} / \mathrm{l}$ of salinity (79$80 \%$ ) (Table 2).
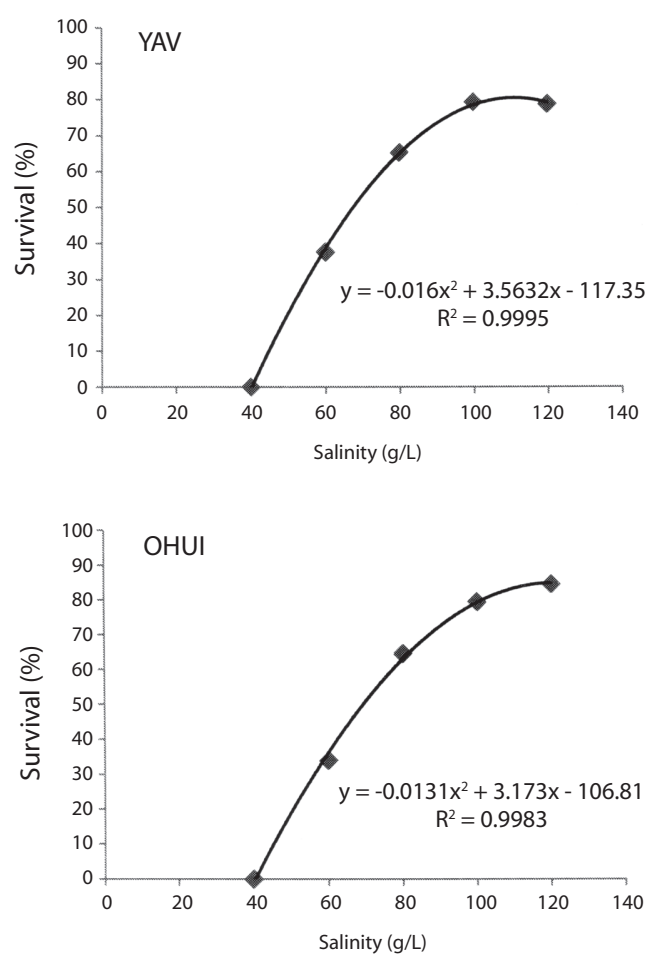

When survival rate at the different salinities were compared, the regression analysis showed a strong correlation $\left(\mathrm{R}^{2}=0.98-0.99\right)$, with a polynomial second grade regression curve (Fig. 1). The actual tendency indicates that as salinity increased, the survival rate decreased.
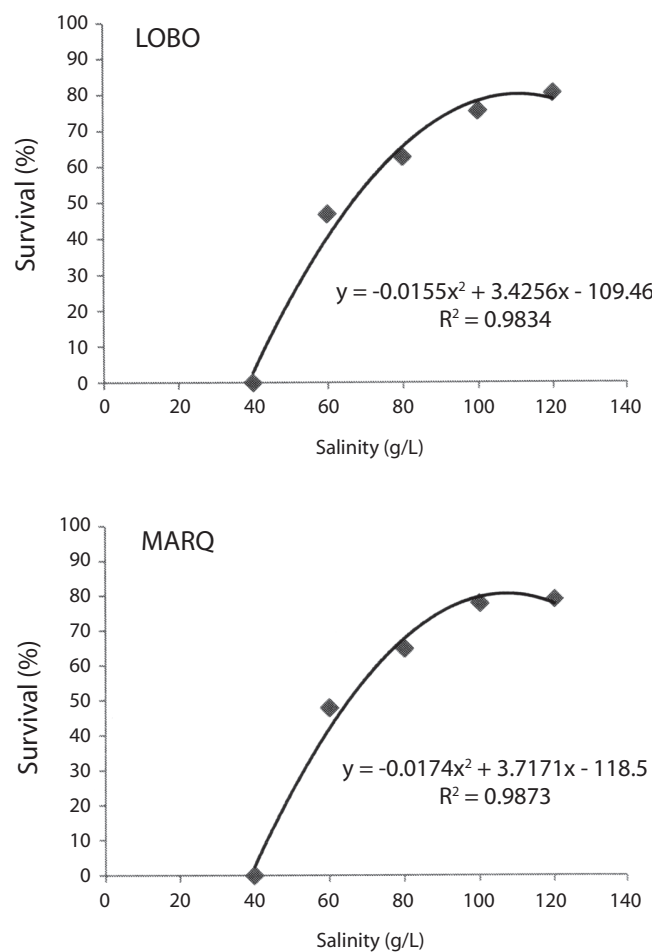

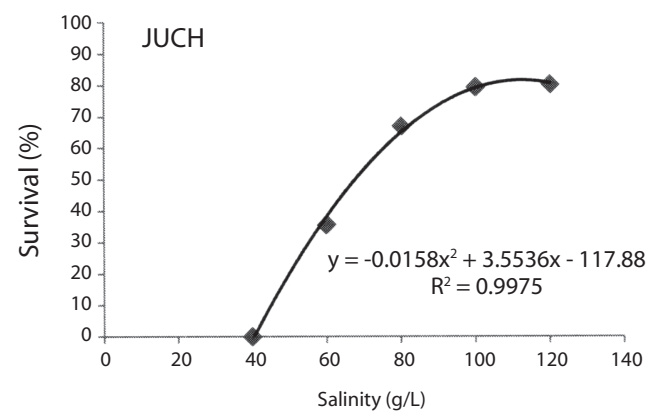

Fig. 1. Survival values and binomial trend line of five Pacific Coast Mexican Artemia populations reared in five different salinities $(40,60,80,100$ and $120 \mathrm{~g} / \mathrm{l})$. 
Growth rate: The total length means \pm standard deviation values of Pacific Coast Mexican Artemia populations are shown in Table 2.

The populations cultivated at $80 \mathrm{~g} / \mathrm{l}$ salinity exhibited the lowest mean growth rate values (6.5-7.5 $\mathrm{mm})$; the populations cultivated at $120 \mathrm{~g} / \mathrm{l}$ salinity showed the highest $(7.8-9.2 \mathrm{~mm})$. Only the LOBO and OHUI populations did not show significant differences (Tukey, $\mathrm{p}<0.05$ ) between all cultured salinities.

When comparing the results of growth rate expressed as total length over the experimental period, the data showed a strong correlation $\left(\mathrm{R}^{2}=0.8513\right)$ with a second grade polynomial curve regression and began to decrease at higher salinities or the organisms died in the juvenile stage (Fig. 2).
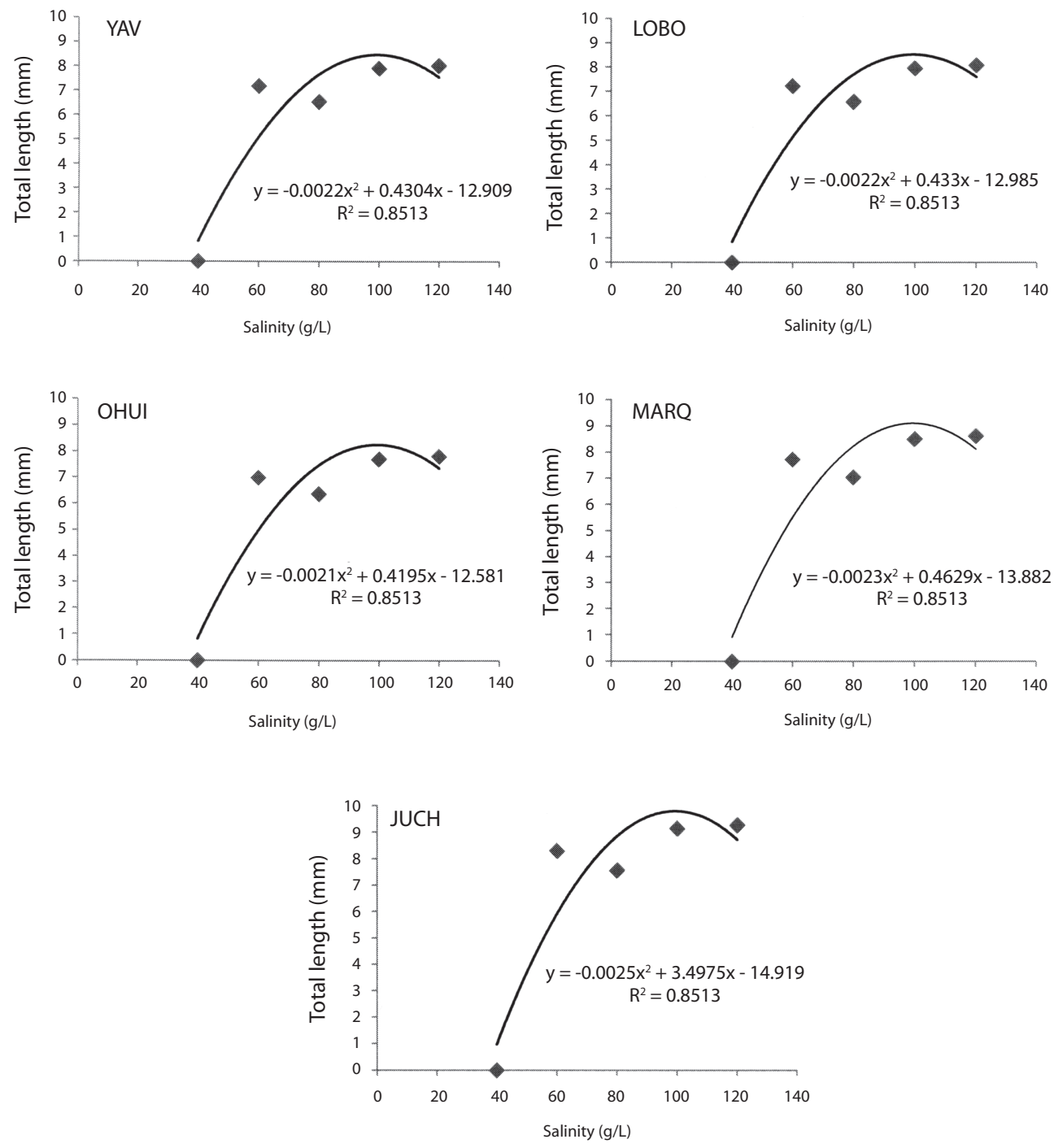

Fig. 2. Growth (with binomial trend line) expressed as total length of five Pacific Coast Mexican A. franciscana populations reared in five different salinities $(40,60,80,100$ and $120 \mathrm{~g} / \mathrm{l})$. 


\section{DISCUSSION}

The survival rates of the five bisexual A. franciscana populations were affected by salinity. The studied populations showed higher mortalities at salinities under $60 \mathrm{~g} / \mathrm{l}$ and over $120 \mathrm{~g} / \mathrm{l}$. It is important to mention that higher mortality rates were observed during metanauplii stage. At $60 \mathrm{~g} / \mathrm{l}$ of salinity, $34-48 \%$ of the hatched nauplii reached the adult stage. Although Mayer (2002), El-Bermawi et al. (2004) and Abatzopoulos et al. (2006a,b) pointed out that bisexual populations do not developed well on salinities between 100-120g/l, the studied Mexican populations showed a different behavior and are like populations of A. parthenogenetica (Litvinenko et al. 2007), A. salina (Naceur et al. 2009) and A. urmiana (Agh et al. 2008).

Agh et al. (2008) mentioned that mortality of $100 \%$ was observed in bisexual populations reared at salinities from 150 to $200 \mathrm{~g} / \mathrm{l}$ and the studied Mexican populations showed a similar pattern, as survival rates decreased over the salinity of $120 \mathrm{~g} / \mathrm{l}$. On the other hand, Abatzopoulos et al. (2006b) reported lower survival values for A. urmiana at salinities of 35 and $50 \mathrm{~g} / \mathrm{l}$, while higher survival rates were at 100 , 140 and $180 \mathrm{~g} / \mathrm{l}$ of salinity.

The survival at high salinities, according Triantaphyllidis et al. (1995) and Van Stappen (2002) might be related to the Artemia osmoregulatory system function, which improves at salinities ranging from 100 to $120 \mathrm{~g} / \mathrm{l}$. As well, Tackaert \& Sorgeloos (1991) have mentioned a genetically imprinted ecological response, which allow the optimal development of brine shrimp at salinities between $100-180 \mathrm{~g} / \mathrm{l}$ as a way to avoid the presence of predators (Rodríguez-Almaraz et al. 2006).

Triantaphyllidis et al. (1995), El-Bermawi et al. (2004) and Agh et al. (2008) reported that growth rate is inversely proportional to salinity. Triantaphyllidis et al. (1995) reported significant differences in A. parthenogenetica growth in Tanggu (China) populations cultured at different salinities. These authors reported that a maximum growth of A. franciscana was observed at $35 \mathrm{~g} / 1(10.16 \pm 0.85 \mathrm{~mm})$. In this research, these species experienced $100 \%$ mortality at $40 \mathrm{~g} / 1$ salinity, and showed better growth at $120 \mathrm{~g} / 1(9.269 \pm 0.263 \mathrm{~mm})$.

The present study confirms that growth and survival rate in these Mexican Pacific coast Artemia populations are inversely proportional to salinity, supporting the findings of Gilchrist (1960), Triantaphyllidis et al. (1995), El-Bermawi et al. (2004) and Agh et al. (2008). In our experiment, the best results are shown in salinities of 100 to $120 \mathrm{~g} / \mathrm{l}$.

The present study supports findings by many studies on the negative impact of salinity values above $120 \mathrm{~g} / \mathrm{l}$ in laboratory cultures (Brown \& Wanigasekera 2000, Baxevanis \& Abatzopoulos 2004, Baxevanis et al. 2004, Agh et al. 2008). In accordance with previous laboratory research on several Artemia species it was found that the optimal range for growth and survival in sexual and asexual strains, lies between 100-120g/l (Triantaphyllidis et al. 1995, Baxevanis et al. 2004, Agh et al. 2008). It is probably that these salinity tests values can be observed having a similar impact in Artemia life span characteristics and reproductive behavior (Agh et al. 2008), suggesting a subject for future experiments.

Thus, it could be concluded that high salinity is a limiting factor to control density, growth and survival of Artemia strains from different regions cultured under laboratory conditions. In other hand, this study would help in the management of the populations of Artemia from the Pacific zone of Mexico. The result information obtained in this study will be useful to produce the Artemia cultures which are widely use as live food in the nearby shrimp and fish farms located on the Mexico Pacific coastal zone.

\section{ACKNOWLEDGMENTS}

This work is part of the doctoral thesis of the first author, who is currently enrolled in the Biological Sciences Ph.D. program at the Universidad Autónoma Metropolitana. 


\section{RESUMEN}

La salinidad es el factor más importante que modifica el crecimiento y la sobrevivencia de las poblaciones mexicanas de Artemia en el mundo. El efecto de este factor en las poblaciones costeras del Pacífico Mexicano ha sido poco estudiado. Cinco poblaciones bisexuales de Artemia provenientes de cuerpos de aguas costeras del Pacífico Mexicano, se estudiaron para determinar el efecto que tiene la salinidad de 40, 60, 80, 100 y $120 \mathrm{~g} / \mathrm{l}$ sobre la sobrevivencia y el crecimiento, en condiciones de laboratorio $\left(25 \pm 2^{\circ} \mathrm{C}, \mathrm{pH} 8\right.$-10; luz y aireación continua). Los experimentos de cultivo fueron realizados en tanques de plástico de 2001. Los valores finales de sobrevivencia y crecimiento fueron determinados después de 21 días de cultivo. Los organismos fueron alimentados con $100 \mathrm{ml} \mathrm{de}$ salvado de arroz y 21 de Tetraselmis suecica (500cel $/ \mathrm{ml}$ ). Las curvas de sobrevivencia y crecimiento fueron determinadas usando un análisis de regresión $\left(\mathrm{R}^{2}\right)$. Las diferencias significativas entre los valores promedio a las distintas salinidades fueron determinadas por una prueba de ANDEVA $(\mathrm{p}<0.05)$. Las mejores tasa de sobrevivencia y crecimiento se encontraron a la salinidad de 100-120g/l. Cuando las poblaciones mexicanas fueron cultivadas a $40 \mathrm{~g} / \mathrm{l}$ de salinidad, hubo una mortalidad del $100 \%$ de los organismos en estadio juvenil. A la salinidad de $80 \mathrm{~g} / \mathrm{l}$, los valores de sobrevivencia y crecimiento, fueron menores que cuando se cultivaron entre 100 y $120 \mathrm{~g} / \mathrm{l}$. Las cinco poblaciones bisexuales de A. franciscana presentaron diferencias significativas en sus tasas de sobrevivencia bajo las salinidades estudiadas. Las tasas de sobrevivencia fueron afectadas por la salinidad. Las poblaciones estudiadas experimentaron alta mortalidad a salinidades por debajo de $60 \mathrm{~g} / \mathrm{l}$ y por arriba de 200g/l. Es importante mencionar que las altas mortalidades se observaron en el estadio metanauplios. El presente trabajo confirma que las tasas de crecimiento de las poblaciones que costeras del Pacífico Mexicano de A. franciscana no son inversamente proporcionales a la salinidad. Las poblaciones de A. franciscana deben de ser cultivadas a una salinidad de $100-120 \mathrm{~g} / \mathrm{l}$ para obtener mejores tasas de sobrevivencia y crecimiento. Estos datos permiten realizar mejoras en los sistemas de cultivo de este crustáceo para la obtención de biomasa para la acuicultura.

Palabras clave: Artemia franciscana, salinidad, crecimiento, sobrevivencia, México, costas del Pacífico.

\section{REFERENCES}

Abatzopoulos, T.J., B. Zhang \& P. Sorgeloos. 1998. Artemia tibetiana: preliminary characterization of a new Artemia species found in Tibet (People's Republic of China). Int. J. Salt Lake Res. 7: 41-44.

Abatzopoulos, T.J., J.A. Beardmore, J.S. Clegg \& P. Sorgeloos. 2002. Artemia: Basic and Applied Biology. Kluwer Academic, Dordrecht, The Netherlands.
Abatzopoulos, T.J., N. El-Bermawi, C. Vasdekis, A.D. Baxevanis \& P. Sorgeloos. 2003. Effects of salinity and temperature on reproductive and life span characteristics of clonal Artemia (International study on Artemia, LXVI). Hydrobiologia 492: 191-199.

Abatzopoulos, T.J., N. Agh, G. Van Stappen, S.M. RazaviRouhani \& P. Sorgeloos. 2006a. Artemia sites in Iran. J. Mar. Biol. Assoc. United Kingdom. 86: 229-307.

Abatzopoulos, T.J., A.D. Baxevanis, G.V. Triantaphyllidis, G. Criel, E.L. Pador, G. Van Stappen \& P. Sorgeloos. 2006b. Quality evaluation of Artemia urmiana Günther (Urmia Lake, Iran) with special emphasis on its particular cyst characteristics (International Study on Artemia, LXIX). Aquaculture 254: 442-454.

Agh, N., G.Van Stappen, G. Bossier, P. Sepehri, H. Lofti, V. Rouhani, S.M.R.P. Sorgeloos. 2008. Effects of salinity on survival, growth, reproductive and life span characteristics of Artemia populations from Urmia Lake and neighboring lagoons. Pak. J. Biol. Sci. 11: 164-172.

Baxevanis, A.D., N. El-Bermawi, T.J. Abatzopoulos \& P. Sorgeloos. 2004. Salinity effects on maturation, reproductive and life span characteristics of four Egyptian Artemia populations. Hydrobiologia 513: 87-100.

Baxevanis, A.D. \& T.J. Abatzopoulos. 2004. The phenotype response of ME2 (M Embolon, Greece) Artemia clone to salinity and temperature. J. Biol. Res. 1: 107-114.

Bowen, S.T., E.A. Fogarino, K.N. Hitchner, G.L. Dana, V.H.S. Chow, M.R. Buoncristiani \& J.R. Carl. 1985. Ecological isolation in Artemia: population differences in tolerance of anion concentrations. J. Crust. Biol. 5: 106-129.

Browne, R.A., S.E. Salee, D.S. Grosch, W.O. Segreti \& S.M. Purser. 1984. Partitioning genetics and environmental components of reproduction and life span in Artemia. Ecology 65: 949-969.

Browne, R.A. \& S.T. Bowen. 1991. Taxonomy and population genetics of Artemia, p. 221-235. In R.A. Browne, P. Sorgeloos \& C.N.A. Trotman CNA (eds.). Artemia Biology. CRC Boca Raton, Florida, USA.

Browne, R.A. \& G. Wanigasekera. 2000. Combined effects of salinity and temperature on survival and reproduction of five species of Artemia. J. Exp. Mar. Biol. Ecol. 244: 29-44.

Castro, M.J. 2004. Caracterización Morfométrica y reproductiva (hibridación) de siete poblaciones de Artemia franciscana en México, en relación a su hábitat y 
latitud. Master Thesis, Universidad Autónoma Metropolitana, México.

Castro, B.T., A.S. Malpica, J.M. Castro, G.M. Castro \& R.A. De Lara. 2000. Environmental and biological characteristics of Artemia ecosystems in México: and updated review, p. 191-202. In M. Munawar, S.G. Lawrence, I.F. Munawar \& D.F. Malley (eds.). Aquatic Ecosystems of México. Status and scope. Backhuys, Leiden, The Netherlands.

Castro, B.T., J.M. Castro \& G.M. Castro. 2003. Artemia, p. 67-81. In T. Castro B. (Comp.) Alimento vivo para organismos acuáticos. AGT, México.

El-Bermawi, N., A.D. Baxevanis, T.J. Abatzopoulos, G. Van Stappen \& P. Sorgeloos. 2004. Salinity effects on survival, growth and morphometry of four Egyptian Artemia populations (International study on Artemia, LXVII). Hydrobiologia 523: 175-188.

Kachigan, S.K. 1991. Multivariate statistical analysis. A conceptual introduction. Radius, New York, USA.

Lenz, P.H. 1987. Ecological studies on Artemia: a review, p. 5-18. In P. Sorgeloos, D.A. Bengtson, W. Decleir \& E. Jaspers (eds.). Artemia Research and its Applications, Vol. 3. Ecology, Culturing, Use in Aquaculture. Universa, Wetteren, Belgium.

Litvinenko, L.I., A.V. Koslov, A.I. Kovalenko \& D.S. Bauer. 2007. Salinity of water as a factor to determine the development of the brine shrimp Artemia populations in Siberian lakes. Hydriobiologia 576: 95-101.

Mayer, R.J. 2002. Morphology and biometry of three populations of Artemia (Branchiopoda: Anostraca) from the Dominican Republic and Puerto Rico. Hydrobiologia 486: 29-38.

Naceur, H.B., A.B. Rejeb-Jenhani \& M.S. Romdhane. 2009. Ecobiological survey of the brine shrimp Artemia salina from Sabkhet El Adhibet (south-east Tunisia). J. Mar. Biol. Assoc. United Kingdom 89: 1109-1116.

Pilla, E.J.S. \& J.A. Beardmore.1994. Genetic and morphologic differentiation in old world bisexual species of Artemia (the brine shrimp). Heredity 72: 47-56.

Post, F.J. \& N.N.Youssef. 1977. A prokaryotick intracellular symbiont of the Great Salt Lake brine shrimp Artemia salina (L.). Can. J. Microbiol. 23: 1232-1236.

Rodríguez-Almaraz, A.G., C. Zavala, R. Mendoza, \& A.M. Maeda-Martínez. 2006. Ecological and biological notes on the brine shrimp Artemia (crustacean:
Branchiopoda: Anostraca) from Carmen Island, Baja California Sur, México. Hydrobiologia 560: 417-423.

Sokal, R.R. \& J.F. Rohlf. 1981. Biometry. W.H. Freeman. San Francisco, California, USA.

Tackaert, W. \& P. Sorgeloos. 1991. Semiintensive culturing in fertilized ponds, p. 287-312. In R.A. Browne, P. Sorgeloos \& C.N.A. Trotman (eds.). Artemia Biology. CRC, Boston, USA.

Tatsuoka, M.M. 1970. Selected topics in advanced statistics. An Elementary Approach. No. 6. Discriminant Analysis. IPAT, Illinois, USA.

Triantaphyllidis, G.V., K. Poulopoulou, T.J. Abatzopoulos, C.A. Pinto-Perez \& P. Sorgeloos. 1995. International study on Artemia XLIX. Salinity effects on survival, maturity, growth, biometrics, reproductive and lifespan characteristics of a bisexual and a parthenogenetic population of Artemia. Hydrobiologia 302: 215-227.

Triantaphyllidis, G.V., G.R.J. Criel, T.J. Abatzopoulos \& P. Sorgeloos. 1997a. International study on Artemia. LIII. Morphological study of Artemia with emphasis to Old World populations. I. Bisexual populations. Hydrobiologia 357: 139-153.

Triantaphyllidis, G.V., G.R.J. Criel, T.J. Abatzopoulos, K.M. Thomas, J. Peleman, J.A. Beardmore \& P. Sorgeloos, 1997b. International study on Artemia. LVII. Morphological and molecular characters suggest conspecificity of all bisexual European and North African Artemia populations. Mar. Biol. 129: 477-487.

Triantaphyllidis, G.V., T.J. Abatzopoulos \& P. Sorgeloos. 1998. Review of the biogeography of the genus Artemia (Crustacea, Anostraca). J. Biogeogr. 25: 213-226.

Vanhaecke, P., S.E. Siddal \& P. Sorgeloos. 1984. International study on Artemia. XXII. Combined effects of temperature and salinity on the survival of Artemia of various geographical origins. J. Exp. Mar. Biol. Ecol. 80: 259-275.

Van Stappen, G. 2002. Zoogeography, p. 171-224. In T.J. Abatzopoulos, J.A. Beardmore, J.S. Clegg \& P. Sorgeloos (eds.), Artemia: Basic and Applied Biology. Kluwer Academic, Dordrecht, The Netherlands.

Wear, R.G. \& S.J. Haslett. 1986. Effects of temperature and salinity on the biology of Artemia fransiscana Kellogg from Lake Grassmere, New Zealand. 1. Growth and mortality. J. Exp. Mar. Biol. Ecol. 98: 153-166. 